\title{
ALBERT CAMUS ENTRE GUERRAS: DE COMBAT A O PRIMEIRO HOMEM
}

ALBERT CAMUS IN BETWEEN WARS: FROM COMBAT TO THE FIRST MAN

\author{
Eurídice Figueiredo ${ }^{1}$
}

Resumo: Este texto aborda textos de Camus no jornal Combat, privilegiando alguns aspectos e articulando-os ao seu último romance, $\mathrm{O}$ primeiro homem, no qual revisita suas origens familiares na Argélia. O jornal Combat, clandestino durante a guerra, apareceu publicamente quando Paris foi libertada, em agosto de 1944. Já O primeiro homem é um romance inacabado que só viria a ser publicado em 1994, quando a imagem do autor, muito desgastada durante a guerra da Argélia, começava a mudar na cena política e cultural francesa. Trata-se de um romance autobiográfico, que tenta reconstituir a vida de seu alter ego assim como a dos seus pais e, de modo geral, a colonização francesa da Argélia.

Palavras-chave: Literatura francesa; Albert Camus; descolonização da Argélia.

\begin{abstract}
This text proposes an analysis of Camus' texts published in the newspaper Combat which privileges some aspects and articulates them with his last novel, The first man in which he revisits his family origins in Algeria. The newspaper Combat, operating underground during the War, appeared publicly after Paris' liberation in August 1944 whereas The first man is an unfinished novel that would only be published in 1994. It was at this time that the author's image, which had suffered greatly during the Algerian war, began to improve in French political and cultural circles. It is an autobiographical novel that narrates his alter ego's life as well as the history of his parents and French colonization in general.
\end{abstract}

Keywords : French Literature; Albert Camus; Algerian decolonization.

\section{Introdução}

Algumas questões estão presentes tanto na obra literária quanto na obra jornalística de Albert Camus: a condição humana, a existência de Deus, a pena de morte, o binômio culpa-inocência, a honestidade no trato com as pessoas, a relação com a natureza, o amor às coisas simples, a singular experiência de ser um homem do Mediterrâneo. Este texto vai abordar textos de Camus no jornal Combat, privilegiando

\footnotetext{
${ }^{1}$ Doutora em Língua e Literatura Francesas pela UFRJ (1988). Professora aposentada atuando como professora permanente no Programa de Pós-Graduação em Estudos de Literatura da UFF. Pesquisadora do CNPq.
} 
alguns aspectos e articulando-os ao seu último romance, $O$ primeiro homem, no qual revisita sua origens familiares na Argélia.

Quando Paris foi libertada em agosto de 1944 e o jornal Combat apareceu publicamente, Albert Camus era um jovem escritor de 31 anos que havia publicado o romance $O$ estrangeiro e o ensaio $O$ mito de Sísifo pela editora Gallimard, ambos em $1942^{2}$. No entanto, estava longe de ser um escritor consagrado, muito menos um intelectual conhecido, já que, nascido na Argélia, portanto, na periferia do império colonial francês, sua entrada no mundo das letras parisiense era recente. Tinha exercido o jornalismo na Argélia, no Alger républicain, de 1938 a 1939. Em 1940 foi para Paris onde trabalhou como secretário de redação do jornal Paris Soir. No início da guerra, tentou se alistar, mas foi dispensado por razões de saúde, já que sofria de tuberculose. Participou da Resistência no jornal Combat, criado por Henry Fresnay para fazer propaganda e convencer os franceses a participar da Resistência e opor-se à Ocupação.

O primeiro número legal do jornal Combat é de 21 de agosto de 1944 e leva o número 59, portanto ele tinha tido 58 números clandestinos. Não se sabe o que Camus escreveu neles, pois não deixou vestígios dessa atividade ilegal, altamente perigosa. O que se pode dizer é que, entre 21 agosto de 1944 e 3 de junho de 1947, Camus publicou 165 textos em Combat: 139 editoriais e 27 artigos, além de outros pequenos textos prováveis. Nem todos têm a mesma importância, nem todos têm sua clara assinatura, porém nenhum texto é anódino, nenhum deixa o leitor indiferente (LEVI-VALENSI, 2002, p. 105). Em setembro de 1945 ele cessou sua colaboração regular enquanto editorialista, mas voltaria a publicar alguns textos nele ${ }^{3}$. Sobre esses dois anos de trabalho à frente de Combat, Camus declarou em entrevista a Jean Daniel, em 1951, publicada na revista Caliban: "Nós fizemos, durante dois anos, um jornal de uma independência absoluta, que nunca sofreu nenhuma desonra. Não pedia nada mais. Tudo dá seus frutos um dia ou outro"״4 (apud LEVI-VALENSI, 2002, p. 103).

Em muitos de seus textos Camus defende a liberdade de imprensa, ameaçada naquele momento em que a França ainda estava em guerra e tudo podia se prestar a censura com a justificativa de que se tratava de "segredos militares". Por outro lado,

\footnotetext{
${ }^{2}$ Além de dois livros em pequenas editoras de Argel (L'envers et l'endroit em 1937 e Noces em 1939), que o público francês não devia conhecer naquele momento.

${ }^{3} \mathrm{O}$ jornal viria a encerrar suas atividades em 1974.

${ }^{4}$ Tradução minha. "Nous avons fait, pendant deux ans, un journal d'une indépendance absolue et qui n'a jamais rien désonhoré. Je ne demandais rien de plus. Tout porte fruit, un jour ou l'autre".
} 
critica o jornalismo sensacionalista, preocupado em dar a notícia em primeiro lugar, sem apurar de maneira conscienciosa todos os fatos. O jornalismo, segundo ele, "uma das mais belas profissões", exige que se busque sempre a verdade. O jornalista é o historiador do dia a dia, assim, o que para o historiador é uma necessidade prática tornase para ele uma lei imperiosa sem o quê sua profissão não passa de má ação (CAMUS, 2002, p. 173). ${ }^{5}$

As dificuldades para o exercício do jornalismo no imediato pós-guerra eram enormes e a concorrência aumentou com o surgimento do Le Monde em dezembro de 1944. Por outro lado, jornais colaboracionistas foram fechados logo depois da Libertação enquanto voltavam à luz do dia jornais da Resistência como Combat, Le Franc-Tireur e France-Soir (que se chamava inicialmente Défense de la France) assim como aqueles que tinham fechado as portas durante a Ocupação, como Le Figaro e Le Populaire.

Camus trata de todos os assuntos: a guerra que ainda não terminou, o governo de de Gaulle, não reconhecido pelos Aliados (que, no entanto, tinham reconhecido, antes de sua queda, o regime de Vichy), os problemas de distribuição de alimentos num país desigual, em que o mercado negro prosperava, fornecendo alimentos para os grandes restaurantes enquanto a população sofria privações, as reformas necessárias para melhorar o nível da política francesa, o papel da ONU, os problemas nas colônias, enfim, os assuntos são bastante variados. Alguns são circunstanciais, específicos daquele momento histórico, o que é próprio do jornalismo, outros têm uma relevância maior, podendo ter ecos até hoje. Serão abordados aqui os assuntos cuja dimensão reflete as posições políticas e éticas de Camus.

\section{A Colaboração e a Depuração no Pós-Guerra}

Uma questão crucial que aparece desde os primeiros textos em 1944 diz respeito à punição dos colaboradores. Trata-se de um posicionamento ético em relação aos culpados, que deviam se haver com a justiça, e, sobretudo, em relação aos inocentes que perderam a vida em campo de batalha. Camus, que havia participado da Resistência, que vira morrer amigos, mostrava-se implacável no sentido de que os traidores da pátria e da honra nacional deviam ser punidos. A ele opôs-se François Mauriac, escritor

\footnotetext{
${ }^{5}$ Tradução minha. Ce qui pour l'historien est une nécessité pratique devient pour lui une loi impérieuse hors de laquelle son métier n'est qu'une mauvaise action.
} 
católico, membro da Academia Francesa, que escrevia no Figaro. A polêmica prima por uma linguagem de alto nível e respeito mútuo embora Mauriac tenha, por vezes, certo ar condescendente com o jovem escritor cuja obra ainda estava por vir. Camus, que era contra a pena de morte, que tinha horror à violência, defendia a punição dos culpados, movido não pelo ódio, mas por um dever de justiça em relação aos mortos que haviam se sacrificado para defender a pátria, enquanto o católico Mauriac preferia falar de caridade e perdão, em parte devido à dificuldade de julgar as pessoas. Em vez de aplicar a justiça, ele apelava à justiça divina.

Em artigo publicado em 25 de outubro de 1944 Camus pedia a repressão imediata para os grandes crimes e, em seguida, o esquecimento dos crimes menores cometidos por tantos franceses. Este foi o período mais difícil da depuração, segundo Henry Rousso (1992), já que a guerra nem tinha acabado. Camus queria que tudo se passasse rápido de maneira a não agravar o clima de ressentimento e de discórdia nacional.

Nós nunca pedimos uma repressão cega e convulsiva. Detestamos o arbitrário e a tolice criminal, gostaríamos que a França conservasse suas mãos puras. Mas desejamos para isso uma repressão imediata dos crimes mais evidentes e, em seguida, já que não se pode fazer nada sem a mediocridade, o esquecimento razoável dos erros que tantos franceses cometeram ${ }^{6}$ (CAMUS, 2002, p. 304-305).

Em 1948, contudo, numa palestra no convento dos dominicanos de LatourMaubourg, ele reconheceu que, na controvérsia que o opôs a Mauriac, a razão estava com Mauriac. Esse mea culpa reflete muito mais a crise pela qual passava Camus (e a França) do que propriamente uma verdade definitiva na querela que opôs os dois intelectuais. Segundo Roger Quilliot (apud CAMUS, 1965, p. 1886), Camus teria ficado muito decepcionado com a depuração devido às injustiças cometidas: advogados de altos funcionários, industriais e chefes militares usaram de mecanismos protelatórios que acabaram salvando-os da condenação, enquanto jornalistas e intelectuais foram condenados à pena de morte em processos rápidos, sumários. Em 1945 e 1946, Camus

\footnotetext{
${ }^{6}$ Tradução minha. "Nous n'avons jamais demandé une répression aveugle et convulsive. Nous détestons l'arbitraire et la sottise criminelle, nous voudrions que la France garde ses mains pures. Mais nous souhaitons pour cela une répression immédiate des crimes les plus évidents, et ensuite, puisqu'on ne peut rien faire sans la médiocrité, l'oubli raisonné des erreurs que tant de Français ont tout de même commises".
} 
assinou petições pedindo a graça para intelectuais condenados (Brasillach, Rebatet). Em janeiro de 1945, ele afirmou que um país que fracassa na sua depuração fracassa também em sua renovação ${ }^{7}$ (CAMUS, 2002, p. 454).

A questão que perturba Camus ao longo desse conturbado período é sua aversão quase epidérmica à pena de morte. Desde $O$ estrangeiro Camus já havia se manifestado, ainda que na chave ficcional, contra a pena de morte. Ele o faria de maneira jurídicofilosófica no ensaio "Reflexões sobre a guilhotina", em 1958, que começa narrando uma cena que se repete em outros textos: seu pai foi assistir a uma execução, voltou para a casa lívido, e vomitou várias vezes. Para um homem que não acreditava na existência do paraíso cristão, a vida era o bem supremo que não se podia retirar de outro ser humano; por outro lado, ninguém é totalmente inocente para condenar os outros, assim como ninguém pode ser considerado totalmente culpado e irrecuperável.

Segundo Rousso, no final da guerra muitas execuções não oficiais, sem julgamento, se deram em meio aos confrontos, sobretudo nas regiões em que a Resistência era mais ativa. A questão da depuração e do julgamento dos colaboradores era muito difícil de ser avaliada no calor da hora.

Precisemos enfim que essas distinções entre as diversas formas de colaboração não tinham na época a clareza que o recuo do tempo hoje nos oferece. Ao contrário, uma das grandes dificuldades da depuração foi precisamente a de chegar a detectar e ponderar os diferentes tipos de delitos e crimes em um contexto muito tenso que não facilitava em nada uma análise calma (ROUSSO, 1992, p. 494) .

A depuração tinha várias funções, que foram mais ou menos cumpridas, segundo Rousso (1992, p. 550): de exutório, de reparação e de justiça em relação às vítimas, de regulação social, de legitimação e de reconstrução nacional. Como ela foi tumultuada e injusta, ela descontentou a todos e não conseguiu erradicar os arautos do fascismo (ROUSSO, 1990, p. 36). Finalmente, a anistia, concedida em $1951^{9}$, foi um atentado à

\footnotetext{
${ }^{7}$ Tradução minha. "Un pays qui manque son épuration se prépare à manquer sa rénovation (...). On voit bien que M. Mauriac a raison, nous allons avoir besoin de la charité".

${ }^{8}$ Tradução minha. "Précisons enfin que ces distinctions entre les diverses formes de collaboration n'avaient pas à l'époque la clarté qu'offre aujourd'hui le recul. Bien au contraire, l'une des grandes difficultés de l'épuration fut précisément d'arriver à cerner et à pondérer les différents types de délits et de crimes, dans un contexte plus que tendu qui ne facilitait guère une analyse sereine".

${ }^{9}$ Inicialmente uma anistia parcial, que se tornou total em 1953.
} 
memória da Resistência. Graças a essa lei, fascistas notórios, nostálgicos de Vichy, puderam não só emergir das sombras como reaver suas prerrogativas públicas, inclusive a de serem eleitos (ROUSSO, 1990, p. 67).

Mas, conforme Camus tinha alertado, a França não conseguiu elaborar o trauma da Ocupação e da Colaboração, e levaria meio século para encarar de frente o seu papel na guerra. Adaptando a lógica da psicanálise aplicada aos casos individuais estudados por Freud, Rousso considera que um país também pode recalcar o trauma e produzir sintomas, sem resolver e enfrentar os problemas. No caso da França, Henry Rousso (1990, p. 18) chamou de "síndrome de Vichy" esse conjunto de sintomas que revela a existência de um trauma ligado à Ocupação e à Colaboração exercida pelo governo de Vichy encabeçado pelo marechal Pétain. Dentre os sintomas, ele cita o do mito da Resistência, criado por de Gaulle, mito que vai se desvanecer a partir dos anos 1970, com a volta do recalcado. ${ }^{10}$ Isso significa, segundo Rousso (1990, p. 75), que o luto não foi elaborado devido a contradições políticas insolúveis. Todos os apelos ao esquecimento e à amnésia entram em oposição com ressurgimentos repetidos. Nem as comemorações nem a justiça são capazes de eliminar as sequelas, sem reabrir, ao mesmo tempo, feridas. "Em suas formas mais simbólicas, a memória oficial parece ser incapaz de unificar as memórias fragmentadas" (ROUSSO, 1990, p. 75) ${ }^{11}$.

\section{Política internacional}

Camus recusava o chamado realismo político, em que concessões são feitas a fim de se obter vantagens; não sendo político, mas, antes, um artista, ele queria que países e políticos fossem coerentes e honestos. Sua atitude em relação à Espanha espelha essa característica que está muito presente em seus textos jornalísticos. Não aceitava que a França e os aliados reconhecessem o governo de Franco, considerando que a França devia uma reparação aos espanhóis, já que o governo de Vichy havia

\footnotetext{
${ }^{10}$ Nos anos 1970 alguns romances e filmes provocaram uma reação forte, ajudando, assim, a iluminar os tempos sombrios da França ocupada. Basta lembrar o filme Lacombe Lucien, realizado por Louis Malle em 1974, a partir de roteiro escrito pelo escritor Patrick Modiano (nascido em 1945, Modiano é obcecado pelo período da Ocupação; publicou seu primeiro romance, Place de l'Etoile, em 1967). Também tiveram forte impacto os documentários sobre os campos de concentração Nuit et brouillard (1956), de Alain Resnais e, trinta anos depois, Shoah (1985), de Claude Lanzmann.

${ }^{11}$ Isso nos remete também ao Brasil, em que só agora, 50 anos depois do golpe militar, se começa a desvendar os porões da ditadura, com as conclusões dos trabalhos da Comissão Nacional da Verdade e das Comissões Estaduais da Verdade. É notável o número de livros publicados nos últimos 5 anos, tanto ficcionais quanto não ficcionais, que tentam tratar daquilo que esteve encoberto durante décadas.
} 
deportado o militante Luis Companys, fuzilado pelos falangistas em Barcelona, em 1940; além disso, a França havia enviado para o campo de concentração de Argelès o poeta Antonio Machado, que morreria ao sair dele. Assim, ele situou a sua peça $O$ estado de sítio na Espanha, o que provocou a ira dos anticomunistas, como o filósofo católico Gabriel Marcel. Em um texto de 25 de novembro de 1948 intitulado "Pourquoi l'Espagne? Réponse à Gabriel Marcel”, ele evoca a cumplicidade da Igreja Católica espanhola com as execuções dos republicanos e lembra que o escritor, também católico, Georges Bernanos, teve atitude diferente ${ }^{12}$. Em tempos de guerra fria, Camus não admitia concessão e mentira. "Pois vocês aceitam silenciar sobre um terror para melhor combater um outro" (CAMUS, 2002, p. 718) ${ }^{13}$.

Apesar de ter aderido ao partido comunista quando jovem, na Argélia, Camus rompeu com ele porque não aceitava nenhum tipo de dogmatismo, tendo debatido publicamente com os comunistas. No momento da guerra fria, em que era preciso escolher um lado ou outro do espectro político, Camus era uma voz solitária porque não podia admitir nem o imperialismo americano nem o totalitarismo soviético. Defendia uma revolução socialista com garantias democráticas e, nesse sentido, se aproximava mais do Partido Socialista, embora tenha feito críticas a ele também. Em 10 de novembro de 1944 ele escreveu: "Em nossa crítica do socialismo havia, e há, uma nostalgia e um lamento: aquele que nasce diante de uma grande ideia reduzida a pequenas práticas e ao espetáculo de uma vocação vivida como uma profissão. Havíamos perdido nossa confiança" (CAMUS, 2002, p. 341). ${ }^{14}$

Um assunto que volta com frequência nos artigos de Camus é a necessidade de encontrar os meios para administrar o mundo de maneira a assegurar a paz mundial. A geração de Camus tinha sofrido as consequências da Primeira Guerra em sua tenra infância: ele - como Roland Barthes, Claude Simon e Jean-Paul Sartre - perdeu o pai, que nem chegou a conhecer. A Segunda Guerra foi, na verdade, um desdobramento da primeira; entretanto, como a França não havia se preparado para a continuação, foi massacrada. A Ocupação foi, para além de toda a violência, uma vergonha nacional. Ao

\footnotetext{
${ }^{12}$ Bernanos se exilou no Brasil de 1938 a 1945 porque se sentiu envergonhado com a pusilanimidade dos políticos franceses. Daqui, enviava artigos em apoio à Resistência.

${ }^{13}$ Tradução minha. Car vous acceptez de faire silence sur une terreur pour mieux en combattre une autre".

${ }^{14}$ Tradução minha. Dans notre critique du socialisme il y avait enfin, et il y a, une nostalgie et un regret: celui qui naît à la vue d'une grande idée ramenée à de petites pratiques et au spectacle d'une vocation vécue comme un métier. Nous avions perdu notre confiance".
} 
falar da Inglaterra, por exemplo, Camus afirma que ela não tinha passado pela desonra de ser ocupada. Os mecanismos para a manutenção da paz no início da guerra fria são tênues. A criação da ONU poderia dar alguma esperança, mas o direito de veto concedido aos cinco grandes - Estados Unidos, Inglaterra, União Soviética, China e França - que são os membros permanentes do Conselho de Segurança, tira qualquer chance de providências efetivas contra uma dessas nações. Ele escreveu em 16 de fevereiro de 1945:

Se a notícia é verdadeira, ela é considerável, pois viria a suprimir toda e qualquer ideia de democracia internacional. O mundo seria, de fato, dirigido por um diretório de cinco potências. As decisões que elas tomassem seriam aplicáveis ao conjunto das nações, mas bastaria que essas decisões se voltassem contra uma delas para que fosse possível que ela se furtasse a acatar devido ao exercício do direito de veto. As cinco conservariam assim, e para sempre, a liberdade de movimento que seria sempre recusada aos outros (CAMUS, 2002, p. 469). ${ }^{15}$

Para instaurar uma verdadeira democracia internacional ele antevê a necessidade de racionalizar o uso comum das matérias primas, sobretudo as mais necessárias, ou seja, a união política da Europa devia passar, antes de mais nada, pelo compartilhamento econômico. Ele escreveu em 3 de dezembro de 1944: "No dia em que forem criadas as bases de uma federação econômica da Europa, a federação política será então possível” (CAMUS, 2002, p. 390). ${ }^{16}$ Ele tinha razão: efetivamente, o primeiro passo na instauração do que hoje é a União Europeia foi a comunidade do carvão e do aço (CECA), criada em 1951 pelo Tratado de Roma, a qual unia os 6 países que formariam a Comunidade Europeia a partir de 1957 (França, Alemanha, Itália, Bélgica, Luxemburgo e Países Baixos). Camus aponta para o problema das nacionalidades e das fronteiras que poderia gerar novos conflitos na Europa, o que de fato aconteceu: a separação da Tchecoslováquia em duas repúblicas (tcheca e eslovaca), a desagregação da antiga Iugoslávia em terríveis conflitos (guerras da Bósnia e do Kosovo), os recentes

\footnotetext{
${ }^{15}$ Tradução minha. "Si la nouvelle est vraie, elle est considérable, car elle reviendrait à supprimer toute idée de démocratie internationale. Le monde serait, en fait, dirigé par un directoire de cinq puissances. Les décisions qu'elles prendraient seraient toujours applicables à l'ensemble des nations, mais il suffirait que ces décisions se retournent contre l'une d'entre elles pour qu'il soit possible à celle-ci de s'y dérober par l'exercice de son droit de veto. Les Cinq garderaient ainsi et toujours la liberté de mouvement qui serait toujours refusée aux autres".

${ }^{16}$ Tradução minha. "Le jour où seront jetées les bases d'une fédération économique de l'Europe, la fédération politique sera alors possible"
} 
conflitos na fronteira da Ucrânia com a Rússia, a anexação da Crimeia pela Rússia, os conflitos religiosos na Irlanda, o terrorismo no País Basco, sem falar em problemas menores que não redundaram em guerras (separatismos na Espanha, dificuldades na governabilidade da Bélgica).

A bomba atômica lançada pelos Estados Unidos sobre Hiroshima em 6 de agosto de 1945, que levaria o Japão à capitulação, foi saudada pela imprensa europeia. Camus não deixa de se alegrar com o término da guerra, porém considera indecente celebrar uma descoberta científica que serve à destruição. "Nós resumiremos em uma frase: a civilização mecânica acaba de chegar ao seu último grau de selvageria. Será preciso escolher, no futuro mais ou menos próximo, entre o suicídio coletivo ou a utilização inteligente das conquistas científicas" (CAMUS, 2002, p. 595). ${ }^{17}$ Os poucos anos que lhe coube viver após o fim da guerra foram tensos porque a ameaça de uma terceira guerra ganhara nova dimensão destruidora após o uso da bomba atômica.

\section{A descolonização: a Argélia}

Sua percepção do processo de descolonização é clara e sua voz é profética quando diz que as civilizações colonizadas fariam ouvir suas vozes e que, em 50 anos, a preeminência da civilização ocidental seria colocada em xeque (CAMUS, 2002, p. 659). Em Combat ele trata não só da Argélia como também da Indochina e de Madagascar, colônias francesas em processo de independência. Ele constata a indiferença e o desconhecimento dos franceses sobre o que acontece nesses países e denuncia os preconceitos e os clichês sobre os árabes.

No plano político gostaria de lembrar também que o povo árabe existe.

Quero dizer com isso que ele não é essa massa anônima miserável em que o ocidental não vê nada a respeitar nem a defender. Trata-se, ao contrário, de um povo de grandes tradições e cujas virtudes estão entre as maiores, basta fazer um pequeno esforço para se aproximar dele sem preconceitos (CAMUS, 2002, p. 522) ${ }^{18}$.

\footnotetext{
${ }^{17}$ Tradução minha. "Nous nous résumerons en une phrase: la civilisation mécanique vient de parvenir à son dernier degré de sauvagerie. Il va falloir choisir, dans un avenir plus ou moins proche, entre le suicide collectif ou l'utilisation intelligente des conquêtes scientifiques"

${ }^{18}$ Tradução minha. "Sur le plan politique, je voudrais rappeler aussi que le peuple arabe existe. Je veux dire par là qu'il n'est pas cette foule anonyme misérable, où l'Occidental ne voit rien à respecter ni à
} 
Ele acusa os franceses de racismo por praticar nas colônias os mesmos métodos de tortura e assassinato que os alemães haviam empregado para reprimir a Resistência francesa. "Três anos depois de ter experimentado os efeitos de uma política de terror, os franceses absorvem essas notícias com a indiferença de homens que viram coisas demais. Entretanto o fato aí está, claro e horrível como a verdade: nós fazemos, nesses casos, o que criticamos os alemães de fazer" (CAMUS, 2002, p. 701) ${ }^{19}$. E ele continua argumentando que o que moveu os alemães foi um sentimento de superioridade de raça. Ora, os franceses combateram os nazistas porque acreditavam que todos eram iguais; no entanto, eles se comportavam com os povos da Indochina, de Madagascar e da África do Norte da mesma maneira que os alemães, com o argumento de que os "Outros" não tinham os mesmos direitos que eles. Como observa Levi-Valensi, na imprensa francesa da época ninguém se exprimia com essa clareza e com essa virulência contra a política colonial.

O centro da preocupação de Camus era a Argélia, terra em que nasceu e viveu até os 27 anos de idade. Ainda no Alger républicain ele havia publicado uma série de 11 artigos, intitulada "Misère de la Kabylie", na qual denunciava os grandes proprietários franceses na Argélia de terem feito tudo para impedir a assimilação dos árabes pela concessão de direitos políticos e, sobretudo, de educação. Ele lembra o projeto de lei Blum-Viollette, proposto em 1937, que garantia a plena cidadania a cerca de 60.000 árabes e que nunca foi votado devido à pressão dos poderosos. $\mathrm{Na}$ época ele, ainda residente em Argel, havia assinado um manifesto em favor da aprovação desse projeto de lei. Em 1944 o governo retomou a ideia do projeto Blum-Viollette que contemplaria 80.000 muçulmanos, mas, mais uma vez, o projeto fracassou por falta de vontade política de melhorar a situação da população árabe.

No imediato pós-guerra, os argelinos, que haviam lutado ao lado dos franceses durante a guerra, esperavam o reconhecimento da França, que não veio (CAMUS, 2002, p. 377). Algum tempo depois, porém, já estavam se preparando para a independência e, sobretudo, já não acreditavam mais nos planos que os franceses faziam e não cumpriam. Em um dos artigos Camus apresenta as propostas de Ferhat Abbas, líder do partido

défendre. Il s'agit, au contraire, d'un peuple de grandes traditions et dont les vertus, pour peu qu'on veuille l'approcher sans préjugés, sont parmi les premières".

${ }^{19}$ Tradução minha. "Trois ans après avoir éprouvé les effets d'une politique de terreur, des Français enregistrent ces nouvelles avec l'indifférence des gens qui en ont trop vu. Pourtant, le fait est là, clair et hideux comme la vérité: nous faisons, dans ces cas-là, ce que nous avons reproché aux Allemands de faire". 
Amis du Manifeste, que propunha o reconhecimento de uma nação argelina ligada à França de maneira federalista na qual o Parlamento teria metade dos deputados muçulmanos e metade de franceses. Ele não exigia uma representatividade exata já que na época a população se dividia entre 8 milhões de arabo-berberes e 1 milhão de franceses. À medida que aumentava a violência da repressão, recrudesciam também os atos terroristas da sublevação dos argelinos. Durante a guerra da Argélia, os franceses usaram métodos de tortura e ocultação de cadáver, tendo eliminado 3.000 pessoas, muitas delas jogadas do alto de aviões, assim como fariam, nos anos 1970, os militares argentinos (GODOY, 2014, p. 77).

Em 1955 Camus voltou à imprensa de maneira regular, escrevendo no semanário L'Express, na esperança de poder contribuir para a solução do problema argelino, já que ele confiava em Pierre Mendès-France, que havia retornado ao governo. Nada foi feito. De 1956 até a sua morte em 1960 foram poucos os seus pronunciamentos na esfera pública sobre a situação na Argélia, onde ainda vivia sua família. Assinou, sem fazer alarde, inúmeros pedidos de clemência contra execuções de árabes.

Recebeu o Prêmio Nobel em 1957, quando estava no ostracismo junto aos intelectuais de esquerda porque se exigia dele uma defesa da independência da Argélia que ele foi incapaz de fazer. Acatando os pedidos dos amigos, em 1958 publicou em livro os textos sobre a Argélia que ele havia escrito ao longo dos anos (Actuelles III Chroniques algériennes). O livro foi ignorado. E o mais trágico é que ele, que durante 20 anos defendeu os direitos dos argelinos, foi acusado de se opor à independência da Argélia porque ele nunca deu seu apoio ao movimento independentista que praticava atos terroristas que podiam atingir sua mãe, conforme ele declarou uma vez. "Se um terrorista jogar uma granada no mercado de Belcourt, frequentado pela minha mãe, e a matar, eu seria responsável no caso em que, para defender a justiça, eu tivesse defendido também o terrorismo. Amo a justiça, mas eu também amo minha mãe" $\left(\right.$ CAMUS, 1965, p. 1843) ${ }^{20}$. Em O primeiro homem, romance que ele estava escrevendo em seus últimos anos de vida, o escritor descreve um ataque terrorista, assustando a mãe de Jacques Cormery, alter ego de Camus. "Sua mãe recuou para o fundo da sala, pálida, os olhos negros cheios de um pavor que ela não conseguia controlar,

\footnotetext{
${ }^{20}$ Tradução minha. "Si un terroriste jette une grenade au marché de Belcourt que fréquente ma mère et s'il la tue, je serais responsable dans le cas où, pour défendre la justice, j'aurais également défendu le terrorisme. J'aime la justice mais j'aime aussi ma mère".
} 
cambaleando um pouco" (CAMUS, 2015, p. 67). Como os ataques eram frequentes, ela tinha medo de sair de casa.

Em 6 de setembro de 1960 foi publicado um texto conhecido como Manifeste des 121 assinado por intelectuais e artistas. Camus tinha morrido no início do ano. Já era tarde demais. Em 1962 foi proclamada a independência. Em seis meses cerca de 700.000 franceses da Argélia, chamados de pieds-noirs, tiveram de deixar o seu país natal. Camus foi uma voz solitária tanto na defesa dos argelinos enquanto havia tempo para uma independência não-traumática quanto nos anos finais em que a violência se exacerbou, tornando-se rotina. E podemos sonhar que, se a independência tivesse se dado de forma mais amigável, a história da Argélia em suas relações com a França seria outra, com a coexistência pacífica de árabes, berberes e descendentes de europeus.

\section{$O$ primeiro homem: a volta às origens na Argélia}

Camus carregava o manuscrito de $O$ primeiro homem quando o carro em que viajava bateu numa árvore, provocando sua morte, em 1960. O livro, inacabado, só viria a ser publicado em 1994, quando sua imagem começava a mudar na cena política e cultural francesa. Trata-se de um romance autobiográfico, que tenta reconstituir a vida de seu alter ego, Jacques Cormery, desde a infância, a vida dos seus pais e, de modo geral, a colonização francesa da Argélia. Diferentemente de seus outros romances, a história contada em $O$ primeiro homem se aproxima demais de sua biografia.

Nascido no bairro pobre de Belcourt, em Argel, em 1913, Camus não conheceu o pai, que morreu na batalha do Marne em 1914. Cresceu, com seu irmão, numa casa dominada pela avó autoritária; além da mãe submissa e resignada, vivia também com a família o tio. O menino Albert era bom aluno e excelente jogador de futebol, experiência que lhe deu o sentido do espírito de equipe. Teve tuberculose na sua juventude, doença que dava períodos de remissão, mas que nunca foi curada. $O$ professor Louis Germain desempenhou o papel de pai na sua infância, quando o valorizou, tratando-o com carinho e indicando-o para uma bolsa a fim de prosseguir os estudos. É por essa razão que no final do volume aparecem duas cartas: uma, de 1957, de Camus para Germain, logo após ter recebido o Nobel, outra, de 1959, de Germain para Camus. Sem a intervenção dele, Camus teria começado a trabalhar, como seu irmão, já que a família era pobre demais para prescindir de sua contribuição. $\mathrm{O}$ 
professor teve de convencer a avó de que ela fazia um bom negócio enviando o pequeno Albert para o colégio. Sem ele, não teria havido Camus escritor, não teria havido Nobel.

O primeiro capítulo, "Intercessora: Viúva Camus”, da primeira parte, intitulada "A procura do pai", é dedicado a sua mãe, analfabeta: "A você, que nunca poderá ler este livro" (CAMUS, 2015, p. 17). A presença, nesses dois títulos, do pai e da mãe, aponta para o significado do romance: a busca das origens, nessa narrativa de filiação. Já na segunda parte, intitulada "O filho ou o primeiro homem”, o personagem-narrador é o primeiro homem, pois antes dele existiram legiões de homens esquecidos.

E ele que quisera escapar do país sem nome, da multidão e da família sem nome, mas em quem algo nunca havia deixado de reivindicar obstinadamente a obscuridade e o anonimato, ele também fazia parte da tribo (...) caminhando na noite dos anos nessa terra de esquecimento onde cada um era o primeiro homem, onde ele próprio precisara educar-se sozinho, sem pai, nunca tendo vivido esses momentos em que o pai chama o filho (...). Ele tinha tentado escapar ao anonimato, à vida pobre, ignorante, obstinada, não pudera viver no mesmo plano dessa paciência cega, sem frases, sem nenhum outro projeto além do imediato. Havia corrido o mundo, construído, criado, rejeitado pessoas, seus dias tinham sido cheios a mais não poder (CAMUS, 2015, p. 151-152).

Apesar de todo o movimento que ele fez para sair desse mundo anônimo, ele espera que a morte o traga de volta "à sua verdadeira pátria" (CAMUS, 2015, p. 152), à terra onde viveram essas pessoas pobres, analfabetas, pouco afeitas à história e à geografia, que não sabem contar suas origens. A reiteração do esquecimento em oposição à memória aponta para o fato que a genealogia é um luxo reservado aos ricos; a própria busca do tempo perdido proustiana é reservada aos burgueses que preservam seus retratos de família, suas casas de campo, suas histórias e suas lendas, passados de geração em geração.

A memória dos pobres já é por natureza menos alimentada que a dos ricos, tem menos pontos de referência no espaço, considerando que eles raramente saem do lugar onde vivem, e tem também menos pontos de referência no tempo de uma vida uniforme e sem cor. É claro que existe a memória do coração, que dizem ser a mais segura, mas o coração se 
desgasta com as dificuldades e o trabalho, esquece mais depressa sob o peso do cansaço. Só os ricos podem reencontrar o tempo perdido. Para os pobres, o tempo marca apenas os vagos vestígios do caminho da morte. E além disso, para poder suportar, não convém se lembrar muito, é preciso ficar mais perto de cada dia, de cada hora, como fazia sua mãe (...) (CAMUS, 2015, p. 72-73).

O sociólogo Pierre Bourdieu (2004, p. 109) fala de si como um trânsfuga porque era filho de pequeno funcionário dos correios e neto de camponês. Graças à educação, ele alçou voo, tornando-se professor do Collège de France e respeitado intelectual. No entanto, isso não se dá sem problemas: ele vive o conflito de se situar no entrelugar, entre dois mundos que se opõem e se desprezam. De um lado, o amor aos pais e aos antigos companheiros de infância, dos quais se envergonha e, ao mesmo tempo, se odeia por tê-los traído; de outro lado, os amigos do novo meio social, com os quais compartilha alta educação e cultura. Essa experiência dual, que cria um "habitus clivado, habitado pelas tensões e as contradições" (BOURDIEU, 2004, p. 127), institui uma relação de ambivalência.

Como Bourdieu, a escritora Annie Ernaux (2011, p. 12), oriunda do meio operário, também considera que aquele que muda de classe social é um trânsfuga para quem nada é simples, nem na vida social, nem no processo de escrita. Mais que os outros escritores, ele se dá conta da fragilidade e do arbitrário da nomeação das coisas, mais do que os outros ele se coloca no coração do imperialismo da língua, de que falava Barthes.

Camus é também um trânsfuga que, ao entrar no liceu, começou a mudar de meio social e a aprender um certo refinamento na linguagem e nos costumes. $\mathrm{Na}$ vida despojada de ornamento e de supérfluo de sua família, até as palavras eram econômicas: na casa do narrador de $O$ primeiro homem não se tinha "cerâmica de Vosges" nem “serviço de Quimper”, só potes, pratos e talheres. O menino só aprende essas palavras sofisticadas na casa de um tio ou de Didier, o amigo da escola de origem burguesa que tinha família na França.

A escola é fundamental para a transformação das crianças oriundas de classes populares porque é aí que têm a possibilidade de abrir seus horizontes e ascender socialmente. Uma escola de qualidade, atenta para as potencialidades de seus alunos, 
faz toda a diferença. No romance, o professor Germain assumiu "sozinho a responsabilidade de arrancá-lo de suas raízes para que fosse em busca de descobertas ainda maiores" (CAMUS, 2015, p. 126).

O romance se constrói entre passado e presente: enquanto o primeiro capítulo se passa em 1913, quando os pais chegam à propriedade que vão administrar, e onde nasce o segundo filho do casal, Jacques, o segundo capítulo se desenrola quarenta anos mais tarde, quando Jacques vai, finalmente, visitar o túmulo do pai. Achava que não tinha muito sentido fazer esse tipo de peregrinação tendo em vista que ele nem conhecera o pai, do qual a mãe nunca falava. A razão da viagem é muito mais o desejo de rever o velho professor, agora já aposentado, que vivia em Saint-Brieuc, na Bretanha. No entanto, diante da lápide de seu pai, dando-se conta que o pai morrera aos 29 anos, portanto, era mais novo do que ele, Jacques começa a sentir que aquele homem "lhe parecia mais próximo agora do que qualquer outra pessoa no mundo" (CAMUS, 2015, p. 34). Essa cena no cemitério evoca Hamlet, que é levado a agir depois do encontro com o pai, que denuncia a trama que o levou à morte; aqui, entretanto, é um encontro mudo com a figura do pai que desencadeia uma volta ao passado, a necessidade de saber mais quem foi Henri Cormery.

Na volta à Argélia para rever a mãe, mais uma vez, passado e presente se alternam. A chegada à casa da mãe é impregnada de emoção: "Jacques cochilava, o coração apertado por uma espécie de angústia feliz com a ideia de rever Argel e a casinha pobre do subúrbio. Isso acontecia toda vez que deixava Paris para ir à África, um júbilo surdo, o coração alargando-se, a satisfação de quem acaba de realizar uma fuga bem-sucedida e ri pensando na cara dos guardas" (CAMUS, 2015, p. 43). O encontro com a mãe, apesar do imenso amor que lhe devota, é frustrante devido à distância que existia entre um escritor adulto e uma velha analfabeta quase surda.

A mãe nunca quis deixar sua casinha no bairro pobre em que sempre viveu, apesar dos atentados frequentes que ameaçavam o seu sossego. As tentativas do filho de levá-la para a França foram inúteis. A figura da mãe revela uma mulher submissa, resignada, com dificuldades de reagir ao autoritarismo da sua própria mãe, sempre calada e um pouco alheia ao que acontece ao seu redor. Frequentemente diante da janela, olhar perdido, a mãe levava uma vida "destituída de esperança", mas, por isso mesmo, desprovida de "qualquer espécie de ressentimento" (CAMUS, 2015, p. 57). 
Através de visitas e conversas, Jacques reconstitui a história da implantação dos franceses na Argélia desde 1848, depois da Comuna de Paris. A família do pai, originária da Alsácia, e a de sua mãe, da Espanha, ambas pobres, fugiam da miséria e de perseguições, como hoje milhões de pessoas fogem em busca de uma terra que as acolha. "Como os espanhóis de Mahón, de quem descendia a mãe de Jacques, ou aqueles alsacianos que em 1871 tinham se recusado a aceitar a dominação alemã e tinham optado pela França" (CAMUS, 2015, p. 149). Entretanto, eles chegam "sob o olhar hostil dos árabes agrupados de longe em longe", se instalam "construindo e trabalhando num país inimigo, que não aceitava a ocupação e se vingava em tudo o que encontrava pela frente" (CAMUS, 2015, p. 146-148).

Camus demonstrava simpatia por essa população francesa da Argélia, de origem humilde, acreditava na possibilidade de existir um país com população multiétnica. No entanto, no presente da enunciação o país está em plena guerra, atentados terroristas, de ambos os lados, explodem, devastando-o. Um proprietário que se recusa a voltar para a França afirma que árabes e franceses foram feitos para se entender. "Tão estúpidos e broncos quanto nós, mas o mesmo tipo de homens" (CAMUS, 2015, p. 142). Seria esta a utopia de Camus?

\section{Conclusão}

Pode-se perceber em seus textos - romances, ensaios, crônicas, contos - a coerência e a honestidade com que trata os mais variados temas, sem seguir nenhuma moda, sem adotar nenhuma igreja e nenhum partido político. No pós-guerra, início da guerra fria, raros foram os intelectuais que se recusaram a cerrar fileiras na linha do liberalismo político americano sem cair nos braços do comunismo soviético. Como ele afirma em "Ni victimes ni bourreaux", série de artigos publicados de 19 a 30 de novembro de 1946 em Combat, ele adotava uma filosofia política relativa, livre de todo tipo de messianismo: "Trata-se, afinal, de definir as condições de um pensamento político modesto, ou seja, livre de todo messianismo e de toda nostalgia do paraíso perdido"21 (CAMUS, 2002, p. 644).

Durante a guerra da Argélia, sem poder interferir a favor de nenhuma das partes em conflito porque não estava de acordo com nenhuma delas, Camus se isolou. Nesse

\footnotetext{
${ }^{21}$ Tradução minha. Il s'agit, en somme, de definir les conditions d'une pensée politique modeste, c'est-àdire délivrée de tout messianisme, et débarrassée de la nostalgie du paradis terrestre.
} 
período dedicou-se à escrita daquele que seria seu último livro, que permaneceu inacabado, $O$ primeiro homem, no qual tece o relato de sua origem, da origem de seus pais, tão pobres e esquecidos, cujas famílias tinham deixado a Europa porque acreditaram na possibilidade de refazer suas vidas na África. Camus teve sua vida afetada por três guerras: a Primeira, que lhe matou o pai, a Segunda, na qual participou, e a da Argélia, que atingiu sua família e manchou sua reputação. Ele tentou entender o seu momento histórico sem dogmatismo, a partir de seu lugar de escritor que veio das margens do império colonial francês, e nem sempre foi bem compreendido.

\section{REFERÊNCIAS}

BOURDIEU, Pierre. Esquisse pour une auto-analyse. Paris:Raisons d'agir Editions, 2004.

CAMUS, Albert. À Combat. Editoriaux et articles, 1944-1947. Edition établie, présentée et annotée para Jacqueline Lévi-Valensi. Paris:Gallimard, 2002.

. Essais. Bibliothèque de la Pléiade. Introduction par R. Quilliot. Textes établis et annotés par R. Quilliot e L. Faucon. Paris:N.R.F., 1965.

. Carnets I. Paris:Gallimard, 1962.

. Carnets II. Paris:Gallimard, 1964.

O primeiro homem. Tradução de Teresa Bulhões Carvalho da Fonseca e Maria Luiza Newlands Silveira. Apresentação de Manuel da Costa Pinto. Rio de Janeiro:Nova Fronteira, 2015.

ERNAUX, Annie. L'atelier noir. Paris:Editions des Busclats, 2011.

GODOY, Marcelo. A casa da vovó. Uma biografia do DOI-CODI (1969-1991), o centro de sequestro, tortura e morte da ditadura militar. Histórias, documentos e depoimentos dos agentes do regime. São Paulo: Alameda, 2014. $2^{\mathrm{a}}$ edição. 
LÉVI-VALENSI, Jacqueline. Un écrivain face à l'histoire. In: CAMUS, Albert. À Combat. Editoriaux et articles, 1944-1947. Edition établie, présentée et annotée para Jacqueline Lévi-Valensi. Paris:Gallimard, 2002. p. 71-109.

ROUSSO, Henry. Le syndrome de Vichy. De 1944 à nos jours. Deuxième édition revue et mise à jour. Paris:Seuil, 1990.

. Vichy. L'événement, la mémoire, l'histoire. Paris:Gallimard, 1992. 